Mery Dafny-Yelin · Inna Guterman · Naama Menda

Mariana Ovadis · Moshe Shalit · Eran Pichersky

Dani Zamir · Efraim Lewinsohn - Zach Adam

David Weiss · Alexander Vainstein

\title{
Flower proteome: changes in protein spectrum during the advanced stages of rose petal development
}

Received: 30 November 2004/ Accepted: 3 February 2005/Published online: 10 May 2005

(C) Springer-Verlag 2005

\begin{abstract}
Flowering is a unique and highly programmed process, but hardly anything is known about the developmentally regulated proteome changes in petals. Here, we employed proteomic technologies to study petal development in rose (Rosa hybrida). Using two-dimensional polyacrylamide gel electrophoresis, we generated stage-specific (closed bud, mature flower and flower at anthesis) petal protein maps with ca. 1,000 unique protein spots. Expression analyses of all resolved protein spots revealed that almost $30 \%$ of them were stagespecific, with ca. 90 protein spots for each stage. Most of the proteins exhibited differential expression during petal development, whereas only ca. $6 \%$ were constitutively expressed. Eighty-two of the resolved proteins were identified by mass spectrometry and annotated. Classification of the annotated proteins into functional groups revealed energy, cell rescue, unknown function
\end{abstract}

Electronic Supplementary Material Supplementary material is available for this article at http://dx.doi.org/10.1007/s00425-005$1512-\mathrm{x}$

M. Dafny-Yelin $\cdot$ I. Guterman $\cdot$ N. Menda $\cdot$ M. Ovadis

D. Zamir $\cdot$ Z. Adam $\cdot$ D. Weiss $\cdot$ A. Vainstein $(\bowtie)$

The Robert H. Smith Institute of Plant Sciences and

Genetics in Agriculture, Faculty of Agricultural,

Food and Environmental Quality Sciences,

The Hebrew University of Jerusalem,

P.O. Box 12, Rehovot, 76100, Israel

E-mail: vain@agri.huji.ac.il

Tel.: +972-8-9489082

Fax: +972-8-9468263

M. Shalit · E. Lewinsohn

Department of Vegetable Crops, Newe Ya'ar Research Center,

Agricultural Research Organization,

P.O. Box 1021, Ramat Yishay,

30095, Israel

E. Pichersky

Department of Molecular,

Cellular and Developmental Biology (MCDB)

University of Michigan, 830 N. University Street,

Ann Arbor, 48109-1048, MI, USA (including novel sequences) and metabolism to be the largest classes, together comprising ca. $90 \%$ of all identified proteins. Interestingly, a large number of stress-related proteins were identified in developing petals. Analyses of the expression patterns of annotated proteins and their corresponding RNAs confirmed the importance of proteome characterization.

Keywords Flower development · Petals ·

Proteome $\cdot$ Rose

Abbreviations 2D-PAGE: Two-dimensional polyacrylamide gel electrophoresis - EST:

Expression sequence tag - IEF: Isoelectric focusing •

ESI-MS/MS: Electrospray ionization mass

spectrometry · MALDI-TOF: Matrix-assisted

laser-desorption time-of-flight · CID: Collision-induced dissociation

\section{Introduction}

The flower's basic architecture is rather simple, despite its almost unlimited variability in showy traits, such as color, fragrance, shape, etc. The constant development of processes generating and fine-tuning these traits has strongly contributed to the evolutionary success of flowering plants. Nevertheless, in many plant systems, petals are the main source of this enormous variability.

Flower development is a uniquely programmed and tightly regulated process (Rolland-Lagan et al. 2003). Two discrete growth phases are distinguishable in petal development: one involves cell division, the other cell expansion (Martin and Gerats 1993; Yu et al. 2004). Very little is known about the genetic machinery involved in corolla-shape determination in general and phase transition in particular: in Gerbera, GEG has been proposed to be involved in the former (Kotilainen et al. 1999) and in Arabidopsis, NAP has been shown to function in the transition from active cell division to cell expansion 
(Sablowski and Meyerowitz 1998). The major increase in petal size occurs during the later stages of flower development, when mitotic activity has basically ceased (Martin and Gerats 1993; Yu et al. 2004). During the cellexpansion phase, various metabolic pathways are activated to produce unique secondary metabolites, e.g. flavonoids, carotenoids and numerous scent compounds (Ben-Meir et al. 2002; Dudareva et al. 2004). With very few exceptions - involving genomic technologies - pathways which are active in petals have been studied via reductionist approaches that are based on identifying and characterizing a single gene/product, mainly in model plants (Vainstein et al. 2001; Dudareva et al. 2004).

For centuries, rose (Rosa hybrida) has been the most important crop in the floriculture industry (Krussmann 1981). With an annual value of ca. $\$ 10$ billion, it is used for both cut flowers and garden plants (VBN 1995; Zuker et al. 1998). Its economic importance also stems from the use of its petals as a source of natural fragrances, flavorings and colorings. As such, the physiology and biochemistry of rose flowers have been studied for years. Nevertheless, only a few molecular studies have been conducted and even in those, research was focused on a single protein/gene. We and others (Channeliere et al. 2002; Guterman et al. 2002) recently used genomics approaches to perform a large-scale study of rose petal functionality at the RNA level. We generated an annotated rose petal EST database of 2,500 unique genes, and rose DNA chips were prepared and used for analyses of the petal transcriptome during flower development in the cell-expansion phase (Guterman et al. 2002; Izhaki 2004). Based on these analyses, several genes involved in the formation of rose aroma were isolated and characterized (Guterman et al. 2002; Lavid et al. 2002; Shalit et al. 2003).

The advances made in high-throughput protein technologies have opened up new possibilities for studying proteomes on a large scale. Improvements made in mass spectrometry (MS) and in 2D gel electrophoresis techniques now allow the highly reproducible resolution of proteins/peptides. These techniques, in combination with the constantly expanding genomic and EST databases, enable the simultaneous characterization/analysis of the expression profiles of a large set of proteins. In the last few years, the first few steps have been made in realizing the potential of protein profiling for the dissection of specific processes in several plant systems (Peltier et al. 2000; Gallardo et al. 2001, 2003; Kruft et al. 2001; Peck et al. 2001; Bae et al. 2003; Watson et al. 2003; Taylor et al. 2004). Nevertheless, almost nothing is known about global proteome changes during flower development. Further, proof of the importance of proteome elucidation can be found in recent studies, which have revealed discrepancies in global gene expression when analyzed at the protein versus RNA level (Gygi et al. 1999; Watson et al. 2003; Johnson et al. 2004).

In the present study, a proteomics approach was used to analyze changes in gene expression during advanced stages of rose petal development. We generated stagespecific petal protein maps and characterized changes in the levels of ca. 1,000 unique protein spots. About $10 \%$ of these proteins were identified, annotated and classified into functional groups. Analyses of the expression patterns of the annotated proteins and their corresponding RNAs confirmed the importance of the proteome characterization.

\section{Materials and methods}

\section{Plant material}

Rose plants ( $R$. hybrida cv. Fragrant Cloud) were grown in pots filled with a mixture of peat and volcanic gravel $(1: 1 \mathrm{v} / \mathrm{v})$ in a greenhouse under controlled temperature $\left(28^{\circ} \mathrm{C} / 20^{\circ} \mathrm{C}\right.$ day/night $)$ and a natural photoperiod. Flower development was divided into three stages. At stage 1, petals start to emerge from the sepal, and their color changes to red. Stage 4 is characterized by rapid petal elongation and further accumulation of pigments. At stage 6, flowers are fully open (Fig. 1).

\section{Protein extraction}

Petals $(1 \mathrm{~g})$ were ground in liquid nitrogen and the resulting powder was extracted with $5 \mathrm{ml}$ buffer containing $0.1 \mathrm{M}$ Tris- $\mathrm{HCl} \mathrm{pH} 8.0,5 \%(\mathrm{w} / \mathrm{v})$ sucrose, $2 \%$ $(\mathrm{w} / \mathrm{v})$ SDS, $5 \%(\mathrm{v} / \mathrm{v}) \beta$-mercaptoethanol and $2 \mathrm{mM}$ PMSF. The extract was mixed with $25 \mathrm{ml}$ of $0.1 \mathrm{M}$ ammonium acetate in methanol, and left overnight at $-20^{\circ} \mathrm{C}$. The mixture was centrifuged at $12,000 \mathrm{~g}$ for $10 \mathrm{~min}$ and the pellet was washed three times with $10 \mathrm{ml}$ ammonium acetate in methanol and once with $5 \mathrm{ml}$ of $80 \%$ acetone. The pellet was then air-dried, solubilized in $0.5 \mathrm{ml}$ rehydration solution containing $8 \mathrm{M}$ urea, $2 \%$ (w/v) CHAPS and $0.5 \%(\mathrm{v} / \mathrm{v})$ immobilized $\mathrm{pH}$ gradient (IPG) buffer pH 3-10 NL (Amersham Pharmacia Biotech, Uppsala, Sweden), and stored at $-70^{\circ} \mathrm{C}$ until use.

\section{Two-dimensional (2D) gel electrophoresis}

Isoelectric focusing (IEF) was performed using an IPGphor instrument (Amersham Pharmacia Biotech) as

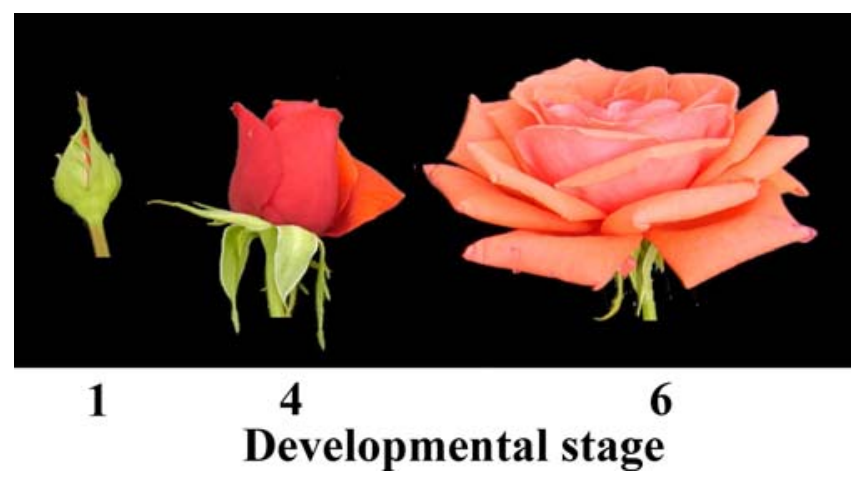

Fig. 1 Rose flowers of cv. Fragrant Cloud at different developmental stages 
previously described (Gorg et al. 1998). Prior to electrophoresis, DTT, to a final concentration of $0.28 \%(\mathrm{w} /$ $\mathrm{v}$ ), and a few grains of bromophenol blue were added to the samples, which were brought to a final concentration of $0.7 \mathrm{mg}$ protein in $250 \mu \mathrm{l}$ rehydration solution. Immobiline dry strips $(13 \mathrm{~cm}, \mathrm{pH} 3-10 \mathrm{NL}$, Amersham Pharmacia Biotech) were rehydrated with the protein sample for $6 \mathrm{~h}$ at $30 \mathrm{~V}$, followed by $6 \mathrm{~h}$ at $60 \mathrm{~V}$. Protein separation was performed at $500 \mathrm{~V}$ for $1 \mathrm{~h}, 2,000 \mathrm{~V}$ for $1 \mathrm{~h}$ and $8,000 \mathrm{~V}$ for $4 \mathrm{~h}$ (for a total of $34,500 \mathrm{~V} / \mathrm{h}$ ).

Following IEF, the gel strips were equilibrated in a buffer consisting of $1.5 \mathrm{M}$ Tris- $\mathrm{HCl} \mathrm{pH} 8.8,6 \mathrm{M}$ urea, $30 \%$ (v/v) glycerol, 2\% SDS, 1\% DTT and bromophenol blue, twice for $15 \mathrm{~min}$. The strips were placed on top of an SDS-polyacrylamide gel, with 5 and $15 \%$ stacking and resolving gels, respectively. Electrophoresis was performed in a standard Tris-Gly running buffer at $25 \mathrm{~mA}$ for $1 \mathrm{~h}$, followed by $35 \mathrm{~mA}$ for $6 \mathrm{~h}$. After electrophoresis, proteins were stained overnight with staining solution containing $0.1 \%(\mathrm{w} / \mathrm{v})$ Coomassie Brilliant Blue R-250, $10 \%(\mathrm{v} / \mathrm{v})$ acetic acid and $45 \%(\mathrm{v} / \mathrm{v})$ methanol. At least three biological and two technical replicates were performed for each analyzed sample.

\section{Gel analysis}

The Coomassie Blue-stained gels were scanned with an ImageScanner (Amersham Pharmacia Biotech). Gel images were analyzed using the ImageMaster 2-D Elite (version 3.01) software (Amersham Pharmacia Biotech). After spot detection and background subtraction (mode: average on boundary), 2D gels were aligned, matched, and a quantitative determination of the spot volumes was performed (mode: total spot normalization). Specific spots were described as up-/down-regulated during flower development when their volumes were significantly different (at least a twofold difference in intensity with non-overlapping errors) in the analyzed gels. Average maps were created from five gels. For the analyses of developmental changes in protein levels three biological replicates (i.e. three different protein extractions) were used.

\section{In-gel proteolysis and MS analysis}

Stained protein spots in the gel (randomly selected) were excised with a razor blade; they were reduced in the gel with $10 \mathrm{mM}$ DTT and modified with $100 \mathrm{mM}$ iodoacetamide in $10 \mathrm{mM}$ ammonium bicarbonate. The gel pieces were treated with $50 \%$ acetonitrile in $10 \mathrm{mM}$ ammonium bicarbonate to remove the stain from the proteins followed by drying. The dried gel pieces were rehydrated with $10 \mathrm{mM}$ ammonium bicabonate containing about $1 \mu \mathrm{g}$ trypsin per sample. The gel pieces were incubated overnight at $37^{\circ} \mathrm{C}$ and the resulting peptides were recovered with $60 \%$ acetonitrile and $0.1 \%$ $(\mathrm{v} / \mathrm{v})$ trifluoroacetate.
The peptides were deposited on a metal target as cocrystals with $\alpha$-cyano-4-hydroxycinnamic acid. The MS analysis was performed using matrix-assisted laserdesorption time-of-flight (MALDI-TOF) (2E, Micromass, UK), in the positive ion mode. The MS data were compared to simulated proteolysis of the Arabidopsis proteins and all plant and rose EST data in "genpept", using Masslynx software (Micromass). Some of the samples were analyzed by liquid chromatography-MS. The tryptic peptides were resolved by reverse-phase chromatography on a $1 \times 150 \mathrm{~mm}$ Vydac C-18 column. The peptides were separated on a linear gradient of 4 to $65 \%$ acetonitrile in $0.025 \%$ trifluoroacetate $\mathrm{A}$, at $1 \%$ per minute and a flow rate of $40 \mu \mathrm{l} /$ min. The liquid from the column was electrosprayed into an ion-trap MS (LCQ, Finnigan, San Jose, CA, USA). MS was performed in the positive-ion mode using a repetitive full MS scan followed by collisioninduced dissociation (CID) of the most dominant ion selected from the first MS scan. The MS data was compared to simulated proteolysis and CID of the proteins in "genpept" using Sequest software (J. Eng and J. Yates, University of Washington and Finnigan, San Jose, CA, USA). Sequence tags were used to screen NR (the non-redundant proteins database), all plant ESTs (EST_pln database), and the Arabidopsis genomic sequence databases as previously described (Guterman et al. 2002).

\section{RNA gel blot analysis}

Total RNA $(10 \mu \mathrm{g})$ was fractionated in a $1 \%$ agarose gel containing formaldehyde and blotted onto Hybond $\mathrm{N}^{+}$ membranes (Amersham Pharmacia Biotech). The blots were hybridized in $0.263 \mathrm{M} \mathrm{Na}_{2} \mathrm{HPO}_{4}, 7 \%$ SDS, $1 \mathrm{mM}$ EDTA, and $1 \%(\mathrm{w} / \mathrm{v}) \mathrm{BSA}$ at $60^{\circ} \mathrm{C}$ with ${ }^{32} \mathrm{P}$-labeled cDNA probes (Rediprime; Amersham Pharmacia Biotech). The membranes were washed twice in 2X SSC and $0.1 \% \mathrm{SDS}$ at $60^{\circ} \mathrm{C}$ for $20 \mathrm{~min}$ each and exposed to $\mathrm{X}$ ray film (Fuji, Tokyo, Japan) with two intensifying screens at $-70^{\circ} \mathrm{C}$.

\section{Collection and analysis of volatiles}

Individual intact rose flowers, still attached to the plants, were enclosed in a 1-1 glass container with the appropriate openings, and headspace was trapped for $24 \mathrm{~h}$ at $25^{\circ} \mathrm{C}$, using a method modified from Raguso and Pichersky (1995), utilizing a Porapak Q 80/100 (Waters Corp., Milford, MA) polydivinylbenzene filter. Volatiles were eluted utilizing $10 \mathrm{ml}$ HPLC-grade hexane containing $100 \mu \mathrm{g}$ ethylmyristate as an internal standard, and evaporated to $0.5 \mathrm{ml}$. A $1-\mu \mathrm{l}$ aliquot of each sample was analyzed by GC-MS (Guterman et al. 2002). The volatile compounds were quantified by integrating the total mass ions detected and comparing to the internal standard (Lavid et al. 2002; Shalit et al. 2003). 


\section{Miscellaneous}

Protein concentration was determined using a Lowry kit (BioRad). Anthocyanins were extracted from $1 \mathrm{~g}$ of fresh rose petals, ground in liquid nitrogen. The resulting powder was extracted with $20 \mathrm{ml}$ of $1 \% \mathrm{HCl}$ in methanol overnight at $20^{\circ} \mathrm{C}$, and the level of anthocyanin was measured spectrophotometrically $\left(A_{530}\right)$. For dry weight determination, petals were placed in an oven at $80^{\circ} \mathrm{C}$ for 3 days.

\section{Results}

Development of rose cv. Fragrant Cloud flowers was divided into six stages, as described previously (Guterman et al. 2002), from a small bud with petals still covered by sepals (stage 1) to a fully open flower at anthesis (stage 6). Flowers at the intermediate stage (stage 4) were characterized by fully pigmented petals that are just beginning to unfurl (Fig. 1). The transition from stage 1 to 4 is accompanied by a three- to fourfold increase in petal fresh and dry weight (Table 1). The protein content of petals (per flower) also increases approximately twofold during this transition. Upon further development of the flower to stage 6 , the fresh weight of petals increases by another $100 \%$, while dry weight and protein content increase by only ca. $40-50 \%$, suggesting that flower growth from stage 4 to 6 is mainly due to cell expansion and water uptake. During flower development, rose petals accumulate anthocyanin pigments and emit volatile compounds. The levels of both increase dramatically during the transition of petals from stage 1 to 4 (Table 1).

To characterize the petal proteome, two-dimensional polyacrylamide gel electrophoresis (2D-PAGE) was carried out with proteins extracted from petals at the three developmental stages. Proteins were first resolved by means of IEF on strips with a nonlinear $\mathrm{pH}$ gradient in the range of 3.0 to 10.0 and then separated in the second dimension by SDS-PAGE and stained with Coomassie Blue. Representative gels (Fig. 2) show protein spots of different intensities at pI values from ca. 4.0 to 8.0 , and molecular masses of ca. 14 to $100 \mathrm{kDa}$.

Average petal protein maps were created for each stage of flower development. Each average gel contained more than 600 protein spots (Table 2). A comparison of the maps revealed 978 different protein spots, of which 421 were present throughout development; the rest appeared in only one or two developmental stages. About
$12 \%$ of the proteins accumulating at each of the three analyzed stages of flower development were stage-specific (Table 2).

To follow the accumulation patterns of proteins during petal development up to anthesis (stage 6), the stain intensities of the different protein spots were evaluated. Protein concentration in the samples, to be analyzed by $2 \mathrm{D}$ gels and representing different stages of flower development, was estimated by Lowry assays and 1D SDS-PAGE was run to confirm equal protein levels in the samples. In addition, to confirm equal loading on the $2 \mathrm{D}$ gels of the proteins from different developmental stages, we followed the level of glyceraldehyde-3-phosphate dehydrogenase (see further on), used in many studies (e.g. see Aubert et al. 2001) as a constitutively expressed reference. We also performed a western blot analysis of a low-molecular-weight heat-shock protein (LMW HSP) identified by 2D gel (spot 137, see further on): its pattern of expression during flower development was essentially identical to that revealed by the analysis of stain intensities on the 2D gel (data not shown).

Petal development from stage 1 to 6 was accompanied by constitutive expression (a less than twofold difference) of 64 proteins, representing 8 to $10 \%$ of the protein spots detectable at each developmental stage. During the early stages ( 1 to 4 ) of petal development (Table 3), the levels of 511 proteins, representing over half of all the different protein spots (899 proteins) detected at these stages, were downregulated (over twofold decrease in expression level). About a quarter of the proteins were upregulated (over twofold increase in expression level), and the expression level of ca. $21 \%$ of the proteins did not differ (less than a twofold change). Similar to the early stages of flower development, during the transition from stage 4 to 6 , the largest group consisted of proteins that are downregulated, representing ca. $40 \%$ of all the different protein spots (886) detected at these stages Essentially the same number of proteins were either upregulated or constitutively expressed in petals during this transition (each group making up ca. $30 \%$ of all the different spots identified at these stages).

In a parallel study, we generated a database containing ca. 3000 ESTs from rose petals at the intermediate stage 4 of development (Guterman et al. 2002; Izhaki 2004). This database was employed to further characterize the rose petal proteome. To annotate petal proteins, different protein spots were excised from gels of stage 4 petals and subjected to MS. Proteins identified by MALDI-TOF and/or electrospray ionization (ESI)-MS/MS analyses, a total of 82 spots (see supplemental data), were annotated

Table 1 Characteristics of rose (cv. Fragrant Cloud) petals at various stages of development

\begin{tabular}{llllll}
\hline $\begin{array}{l}\text { Developmental } \\
\text { stage }\end{array}$ & $\begin{array}{l}\text { Fresh weight } \\
(\mathrm{g} / \text { flower })\end{array}$ & $\begin{array}{l}\text { Dry weight } \\
(\mathrm{g} / \text { flower })\end{array}$ & $\begin{array}{l}\text { Protein } \\
(\mathrm{mg} / \text { flower })\end{array}$ & $\begin{array}{l}\text { Anthocyanins } \\
\left(A_{530} / \text { flower }\right)\end{array}$ & $\begin{array}{l}\text { Volatiles } \\
(\mu \mathrm{g} / \text { flower 24 h) }\end{array}$ \\
\hline 1 & $1.3 \pm 0.1$ & $0.2 \pm 0.02$ & $406.3 \pm 27.4$ & $1.4 \pm 0.2$ & $5.3 \pm 0.4$ \\
4 & $4.4 \pm 0.4$ & $0.9 \pm 0.10$ & $838.8 \pm 38.6$ & $20.3 \pm 1.3$ & $168.1 \pm 83.1$ \\
6 & $9.4 \pm 0.3$ & $1.3 \pm 0.10$ & $1151.5 \pm 29.4$ & $22.7 \pm 2.4$ & $42.0 \pm 18.4$ \\
\hline
\end{tabular}

Values represent means of four replicates $\pm \mathrm{SE}$ 

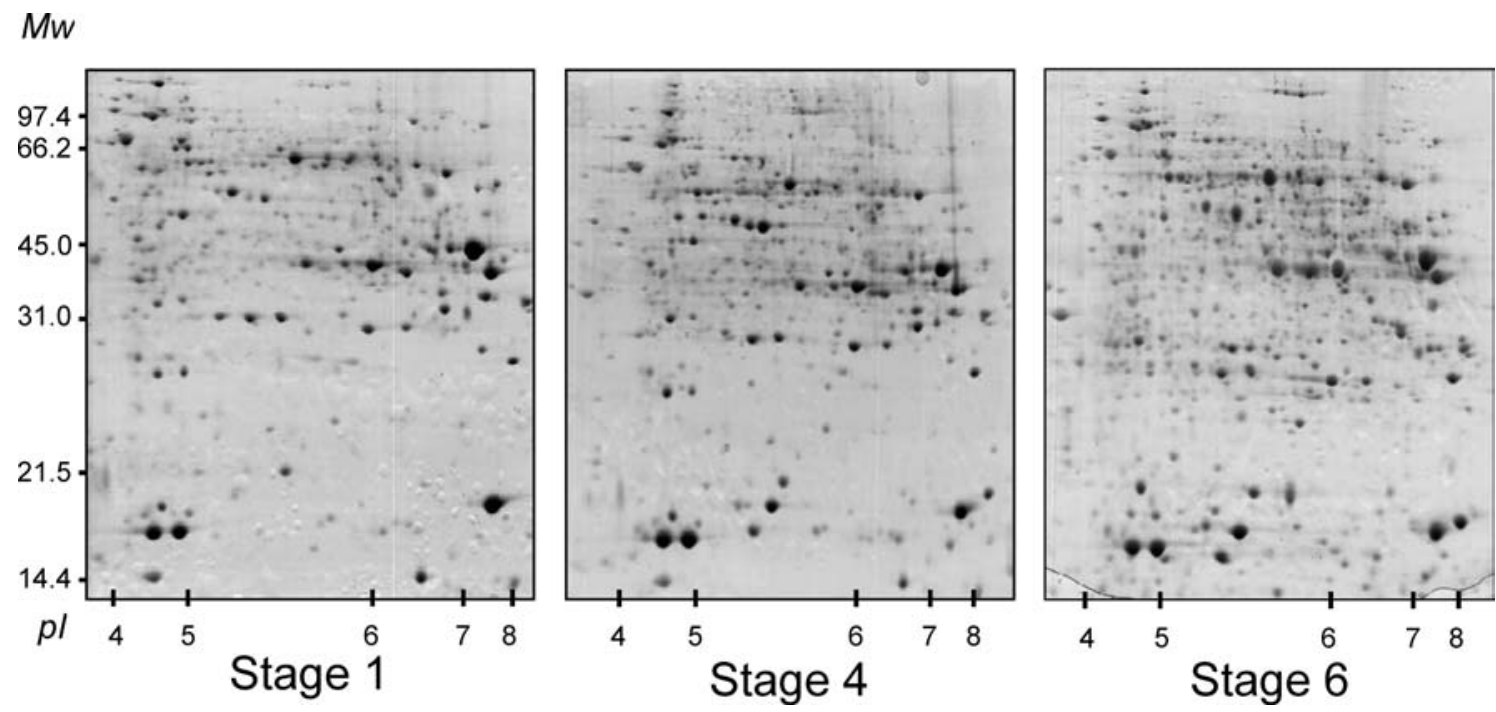

Fig. 2 Reference maps of rose petal proteins at different developmental stages. Proteins were extracted from petals at three different developmental stages and equal amounts were separated by 2D-PAGE. Representative gels for each stage, stained with Coomassie Blue, are presented

on a master gel (Fig. 3). Since the sequence information in rose is mainly from an EST database (i.e. partial sequence only), almost all theoretical MW and pI values for identified spots are based on genomic databases of plants other than rose. This may explain the relative lack of fit observed in several cases between the experimental and theoretical values, e.g. spots \#98, 123.

Among the annotated proteins, 11 groups of spots were characterized, each consisting of two to four proteins with different molecular masses and/or pIs but apparently encoded by the same gene (Table 4). Proteins in these groups may have arisen from post-translational modifications, alternative splicing, allelic variation, etc.

The identified proteins were classified into functional groups according to the Munich Information Center for Protein Sequences (MIPS, http://mips.gsf.de). The largest group contained proteins ( $26 \%$ of total annotated) with a putative function in energy (Table 4).

Table 2 Distribution of rose petal protein spots during flower development

\begin{tabular}{llll}
\hline $\begin{array}{l}\text { Developmental } \\
\text { stage }\end{array}$ & $\begin{array}{l}\text { Protein } \\
\text { spots (no.) }\end{array}$ & \multicolumn{2}{l}{ Stage-specific } \\
\cline { 3 - 4 } & & No. & $\begin{array}{l}\text { \% of } \\
\text { total }\end{array}$ \\
\hline 1 & 735 & 92 & 12.5 \\
4 & 766 & 94 & 12.3 \\
6 & 611 & 79 & 12.9 \\
1,4 & & 181 & \\
4,6 & & 70 & \\
1,6 & & 41 & \\
$1,4,6$ & & 421 & \\
\hline
\end{tabular}

Spots revealed by 2D-PAGE (five gels) of proteins extracted from petals at three different developmental stages, presented in Fig. 2, were counted. These gel images were overlaid and spots present in only one stage were characterized as stage-specific proteins. The number of protein spots present in two (stages 1 and 4; stages 4 and 6; stages 1 and 6) and three (stages 1, 4 and 6) developmental stages is also shown
Proteins classified into cell-rescue categories and those with unknown function represented the next largest groups, with ca. $18 \%$ of total identified proteins each. Similarly, proteins with putative function in metabolism represented ca. $17 \%$ of the total identified proteins. A much smaller number of identified proteins belonged to the other functional categories.

Two proteins $(\# 78,102)$ could be identified only in the rose EST database (BQ104638 and BQ104241, respectively). These ESTs have no homologues in other databases, as revealed by BLAST analysis against NR (nonredundant proteins database), all plant ESTs (EST_pln) and the Arabidopsis genomic sequences. Five additional proteins from the no-hit category could have been identified in the database based on tryptic peptide sequences of ESI-MS/MS. Nevertheless, since their theoretical MWs differed greatly (by over $20 \%$ ) from the experimental values, these proteins were classified in the no-hit category.

Table 3 Expression profiling of petal proteins during rose flower development

\begin{tabular}{|c|c|c|c|c|}
\hline \multirow{3}{*}{$\begin{array}{l}\text { Expression } \\
\text { pattern }\end{array}$} & \multicolumn{4}{|c|}{ Developmental stages } \\
\hline & \multicolumn{2}{|c|}{ From 1 to 4} & \multicolumn{2}{|c|}{ From 4 to 6} \\
\hline & No. & $\%$ & No. & $\%$ \\
\hline Downregulated proteins & 511 & 56.8 & 356 & 40.2 \\
\hline Upregulated proteins & 197 & 21.9 & 248 & 28.0 \\
\hline Constitutive proteins & 191 & 21.3 & 282 & 31.8 \\
\hline
\end{tabular}

Proteins extracted from petals at three different developmental stages were separated by 2D-PAGE and average spot intensities were compared. Proteins whose level increased or decreased more than twofold during flower development, as revealed by the intensity of Coomassie Blue stain, were considered upregulated or downregulated, respectively: 899 and 886 different protein spots were identified in stages 1 to 4 and 4 to 6 , respectively. All spots with an at least twofold difference in intensity have non-overlapping errors 


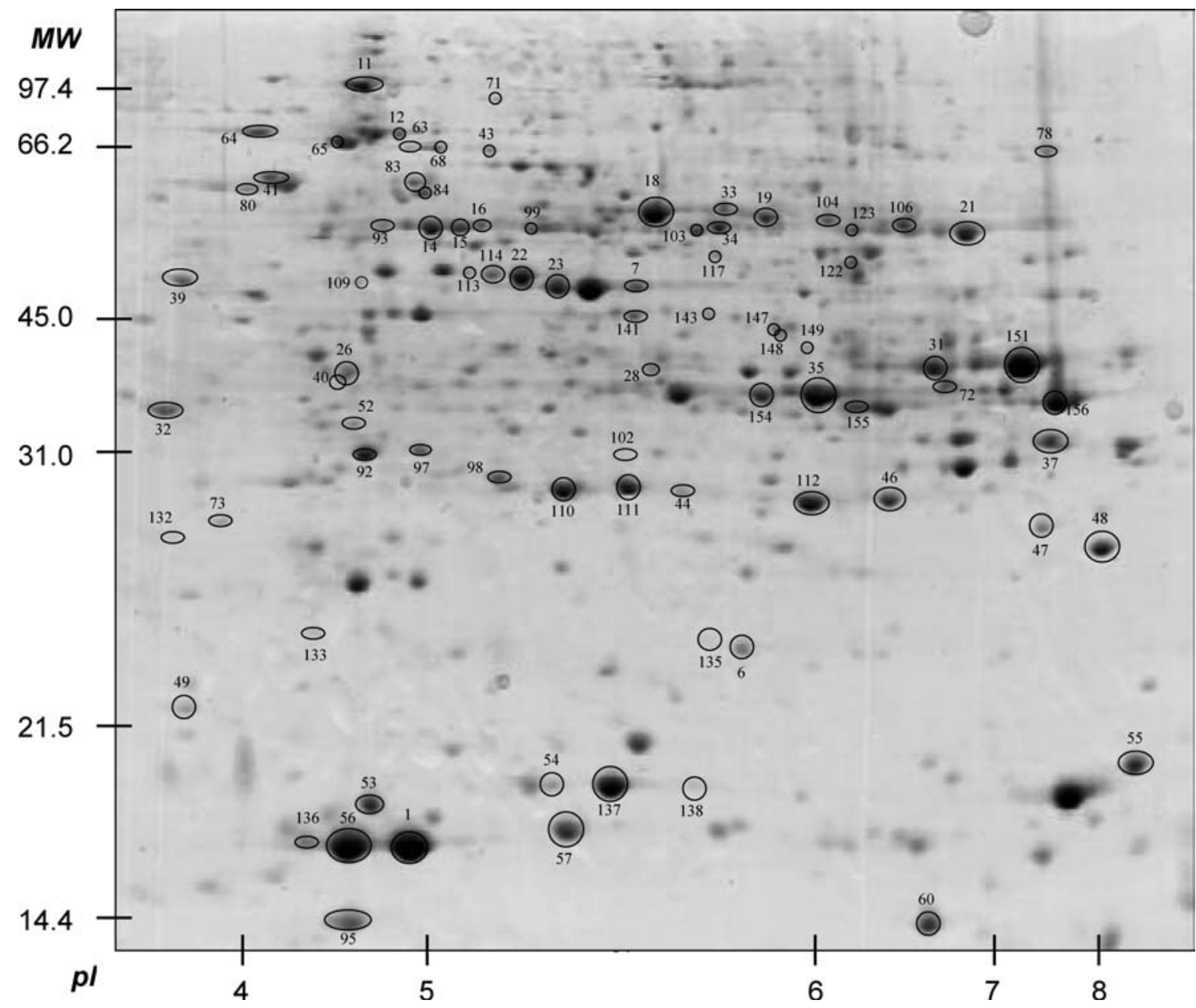

Fig. 3 Proteins identified by mass spectrometry. Identification numbers of circled proteins identified by mass spectrometry (see Table 4) are presented on the reference map of proteins extracted from stage- 4 petals

Expression pattern at the RNA level was analyzed for several rose genes. Four genes, whose expression during flower development from stage 1 to 6 had been determined at the protein level, were studied (Fig. 4). Of the three proteins corresponding to BQ105069 (\#1, 56, 136), only protein \#136's expression corresponded to that of the RNA. Similarly, only a partial correlation was observed between the expression pattern of BQ106020 RNA and expression of the two corresponding proteins, \#137 and 54. For BQ105169, expression at the RNA level was upregulated during flower development, while the level of the corresponding protein increased from stage 1 to 4 but then remained constitutive. The pattern of BQ104538 transcript accumulation also did not correspond to that of the encoded protein \#123 during flower development. These results demonstrate discrepancies in gene expression at the RNA vs. protein levels. We also harnessed the available data from microarray experiments that followed transcript levels in petals of developing cv. Fragrant Cloud flowers (Guterman et al. 2002, Izhaki 2004). A comparison of the changes in expression (from stage 1 to 4 ) of genes coding for the identified proteins at the RNA and protein levels again revealed a lack of consistency in ca. $62 \%$ of the cases (Table 4 ).

\section{Discussion}

Advances in proteomics tools (Kruft et al. 2001; Bardel et al. 2002; Gallardo et al. 2002; Roberts 2002; Taylor et al. 2004) allowed us to assess rose petal development on a large scale at the protein level. 2D-PAGE was performed with total proteins extracted from petals at three different developmental stages. The sum of these three protein maps yielded ca. 2,000 protein spots and alignment of these maps revealed ca. 1,000 different protein spots. Almost $60 \%$ of these different proteins were not detectable at all three stages of flower development, with ca. $30 \%$ being stage-specific. These protein-expression dynamics suggest that numerous programs/pathways are activated/deactivated during the petal transition from stage 1 to 6 , even though major changes, such as cell differentiation and division, have already ceased prior to stage 1 of flower development (Chmelnitsky et al. 2002). Advanced stages of rose petal growth (stage 1 to 6), as in many other plants, are due to cell expansion, which follows the cell-division phases. During the cell-expansion phase, the petals accumulate high levels of pigment (Weiss 2000). In parallel, high levels of volatiles are 
Table 4 Functional classification and expression analyses of the identified rose petal proteins. Protein spots excised from Coomassie Bluestained gels were subjected to digestion with trypsin and identified following mass spectrometry analysis (either ESI-MS/MS or MALDITOF, see supplemental data)

\begin{tabular}{|c|c|c|c|c|c|c|c|}
\hline \multirow[t]{2}{*}{$\begin{array}{l}\text { Spot } \\
\text { no. }\end{array}$} & \multirow[t]{2}{*}{$\begin{array}{l}\text { Accession } \\
\text { no. }\end{array}$} & \multirow[t]{2}{*}{$\begin{array}{l}\text { Putative } \\
\text { function/description }\end{array}$} & \multirow[t]{2}{*}{$\begin{array}{l}\text { Exp. } \\
\text { MW (kDa) }\end{array}$} & \multirow[t]{2}{*}{$\begin{array}{l}\text { Exp. } \\
\text { pI }\end{array}$} & \multirow[t]{2}{*}{$\begin{array}{l}\text { Theo. } \\
\text { MW (kDa) }\end{array}$} & \multirow[t]{2}{*}{$\begin{array}{l}\text { Theo. } \\
\text { pI }\end{array}$} & $\begin{array}{l}\text { Expression protein } \\
\text { RNA }\end{array}$ \\
\hline & & & & & & & $1-4$ \\
\hline
\end{tabular}

\begin{tabular}{|c|c|c|c|c|c|c|c|c|c|}
\hline \multicolumn{10}{|l|}{ Energy } \\
\hline & BQ105894 & Mitochondrial ATP synthase $\beta$-subunit & 55.7 & 5.0 & 60.3 & 6.0 & $\mathrm{c}$ & $\mathrm{c}$ & $\mathrm{c}$ \\
\hline 15 & BQ105894 & Mitochondrial ATP synthase $\beta$-subunit & 55.7 & 5.1 & 60.3 & 6.0 & c & $\mathrm{c}$ & $\mathrm{c}$ \\
\hline 16 & BQ105894 & Mitochondrial ATP synthase $\beta$-subunit & 56.2 & 5.2 & 60.3 & 6.0 & $\mathrm{~d}$ & $\mathrm{c}$ & $\mathrm{c}$ \\
\hline 93 & BQ105894 & Mitochondrial ATP synthase $\beta$-subunit & 55.7 & 4.7 & 60.3 & 6.0 & $\mathrm{u}$ & $\mathrm{c}$ & $\mathrm{c}$ \\
\hline 48 & BQ105229 & ATP synthase subunit & 24.6 & 7.8 & 27.6 & 6.3 & $\mathrm{c}$ & $\mathrm{c}$ & $\mathrm{c}$ \\
\hline 33 & AAB01582 & ATP synthase $\alpha$-subunit & 59.0 & 5.7 & 55.3 & 6.5 & $\mathrm{c}$ & $\mathrm{c}$ & \\
\hline 53 & BQ104437 & $\begin{array}{l}\text { Mitochondrial } F_{0} \text { ATP } \\
\text { synthase D chain }\end{array}$ & 18.7 & 4.7 & 19.6 & 5.1 & $\mathrm{~d}$ & $\mathrm{~d}$ & $\mathrm{c}$ \\
\hline 18 & BQ104782 & Enolase & 58.4 & 5.5 & 47.9 & 5.6 & $\mathrm{c}$ & $\mathrm{c}$ & $\mathrm{d}$ \\
\hline 103 & BQ104782 & Enolase & 55.3 & 5.6 & 47.9 & 5.6 & $\mathrm{c}$ & $\mathrm{c}$ & $\mathrm{d}$ \\
\hline 117 & BQ104782 & Enolase & 50.52 & 5.6 & 47.9 & 5.6 & $\mathrm{c}$ & $\mathrm{u}$ & $\mathrm{d}$ \\
\hline 19 & BQ105613 & Enolase & 57.5 & 5.8 & 47.9 & 5.6 & $\mathrm{~d}$ & $\mathrm{c}$ & $\mathrm{c}$ \\
\hline 151 & CF349790 & Cytosolic aldolase & 36.3 & 7.2 & 38.5 & 6.9 & $\mathrm{~d}$ & $\mathrm{u}$ & $\mathrm{c}$ \\
\hline 31 & CF349790 & Cytosolic aldolase & 36.3 & 6.5 & 38.5 & 6.9 & $\mathrm{u}$ & $\mathrm{c}$ & $\mathrm{c}$ \\
\hline 143 & CF349790 & Cytosolic aldolase & 42.1 & 5.6 & 38.5 & 6.9 & $\mathrm{~d}$ & $\mathrm{c}$ & $\mathrm{c}$ \\
\hline 35 & BQ103935 & Malate dehydrogenase & 33.7 & 6.0 & 35.6 & 8.7 & $\mathrm{c}$ & $\mathrm{c}$ & $\mathrm{d}$ \\
\hline 154 & BQ103935 & Malate dehydrogenase & 33.7 & 5.8 & 35.6 & 8.7 & $\mathrm{c}$ & $\mathrm{c}$ & $\mathrm{d}$ \\
\hline 104 & BQ105334 & Glycine hydroxymethyltransferase & 59.3 & 6.0 & 57.4 & 8.1 & $\mathrm{c}$ & $\mathrm{d}$ & $\mathrm{c}$ \\
\hline 148 & BQ104363 & Phosphoglycerate kinase & 40.6 & 5.9 & 42.1 & 5.5 & $\mathrm{~d}$ & $\mathrm{~d}$ & \\
\hline 155 & CAB43638 & $\begin{array}{l}\text { NAD }(\mathrm{P}) \mathrm{H} \text { oxidoreductase, } \\
\text { isoflavone reductase }\end{array}$ & 31.2 & 6.1 & 34.1 & 6.3 & $\mathrm{u}$ & $\mathrm{d}$ & \\
\hline 147 & AAC49964 & $\begin{array}{l}\text { NAD }^{+} \text {-dependent isocitrate } \\
\text { dehydrogenase }\end{array}$ & 40.7 & 5.8 & 39.6 & 8.4 & $\mathrm{~d}$ & $\mathrm{~d}$ & \\
\hline 149 & AAM61498 & $\begin{array}{l}\mathrm{NAD}^{+} \text {-dependent isocitrate } \\
\text { dehydrogenase subunit } 1\end{array}$ & 39.9 & 6.0 & 39.6 & 8.4 & $\mathrm{c}$ & $\mathrm{c}$ & \\
\hline \multicolumn{10}{|c|}{ Cell rescue, defense, cell death and ageing } \\
\hline 54 & BQ106020 & LMW HSP & 18.8 & 5.3 & 17.4 & 6.2 & $\mathrm{u}$ & $\mathrm{u}$ & $\mathrm{u}$ \\
\hline 137 & BQ106020 & LMW HSP & 18.8 & 5.4 & 17.4 & 6.2 & $\mathrm{u}$ & $\mathrm{c}$ & $\mathrm{u}$ \\
\hline 57 & BQ105169 & LMW HSP & 18.8 & 5.4 & 17.5 & 5.6 & $\mathrm{u}$ & $\mathrm{c}$ & $\mathrm{u}$ \\
\hline 55 & BQ105353 & LMW HSP & 19.1 & 8.0 & 18.2 & 5.4 & $\mathrm{c}$ & $\mathrm{u}$ & $\mathrm{u}$ \\
\hline 64 & BQ104691 & HSP70 & 78.6 & 4.1 & 75.5 & 5.2 & $\mathrm{c}$ & $\mathrm{c}$ & \\
\hline 65 & BQ104443 & HSP70 & 75.5 & 4.6 & 71.4 & 5.0 & $\mathrm{~d}$ & $\mathrm{u}$ & $\mathrm{c}$ \\
\hline 68 & CF349319 & HSP 70 & 74.0 & 5.0 & 71.2 & 5.3 & $\mathrm{~d}$ & $\mathrm{u}$ & $\mathrm{c}$ \\
\hline 12 & CF349462 & HSP70 & 77.9 & 4.8 & 70.9 & 5.4 & $\mathrm{u}$ & $\mathrm{c}$ & $\mathrm{u}$ \\
\hline 110 & CF349827 & L-ascorbate peroxidase & 27.4 & 5.4 & 27.9 & 5.9 & $\mathrm{c}$ & $\mathrm{c}$ & $\mathrm{c}$ \\
\hline 111 & CF349827 & L-ascorbate peroxidase & 27.5 & 5.5 & 27.3 & 5.7 & $\mathrm{c}$ & $\mathrm{c}$ & $\mathrm{c}$ \\
\hline 135 & CF349736 & Superoxide dismutase & 23.7 & 5.6 & 25.4 & 8.5 & $\mathrm{u}$ & $\mathrm{c}$ & $\mathrm{c}$ \\
\hline 6 & CF349736 & Superoxide dismutase & 23.6 & 5.7 & 26.3 & 6.7 & $\mathrm{c}$ & $\mathrm{c}$ & $\mathrm{c}$ \\
\hline 32 & BQ105483 & $\begin{array}{l}\text { Chromoplast carotenoid-associated } \\
\text { protein }(\mathrm{ChrC})\end{array}$ & 32.6 & 3.6 & 35.2 & 5.2 & $\mathrm{u}$ & $\mathrm{u}$ & $\mathrm{u}$ \\
\hline 122 & CF349678 & Catalase & 47.6 & 6.1 & 56.9 & 6.6 & $\mathrm{c}$ & $\mathrm{c}$ & $\mathrm{c}$ \\
\hline 133 & CAA71503 & 2-Cys peroxiredoxin & 23.7 & 4.4 & 28.9 & 8.8 & $\mathrm{~d}$ & $\mathrm{c}$ & \\
\hline \multicolumn{10}{|c|}{ Metabolism } \\
\hline 7 & BQ106376 & $S$-adenosylmethionine synthetase & 46.0 & 5.5 & 42.9 & 5.4 & $\mathrm{c}$ & $\mathrm{c}$ & $\mathrm{u}$ \\
\hline 22 & BQ106376 & “ & 47.0 & 5.3 & 43.3 & 5.7 & $\mathrm{c}$ & $\mathrm{c}$ & $\mathrm{u}$ \\
\hline 23 & BQ106376 & $S$-adenosylmethionine synthetase & 45.7 & 5.3 & 43.1 & 5.5 & $\mathrm{u}$ & $\mathrm{d}$ & $\mathrm{u}$ \\
\hline 114 & BQ106376 & $S$-adenosylmethionine synthetase & 47.7 & 5.2 & 42.9 & 5.7 & $\mathrm{c}$ & $\mathrm{c}$ & $\mathrm{u}$ \\
\hline 112 & BQ106102 & Triosephosphate isomerase & 26.7 & 5.9 & 27.1 & 5.5 & $\mathrm{c}$ & $\mathrm{c}$ & $\mathrm{c}$ \\
\hline 44 & BQ106102 & Triosephosphate isomerase & 27.4 & 5.6 & 27.1 & 5.5 & $\mathrm{u}$ & $\mathrm{d}$ & $\mathrm{c}$ \\
\hline 98 & BQ106556 & Triosephosphate isomerase & 28.0 & 5.2 & 33.3 & 7.7 & $\mathrm{~d}$ & $\mathrm{c}$ & $\mathrm{c}$ \\
\hline 46 & BQ106636 & Triosephosphate isomerase & 26.9 & 6.3 & 27.1 & 5.5 & $\mathrm{c}$ & $\mathrm{c}$ & $\mathrm{c}$ \\
\hline 156 & CF349690 & $\begin{array}{l}\text { Glyceraldehyde-3-phosphate } \\
\text { dehydrogenase }\end{array}$ & 33.3 & 7.4 & 39.1 & 6.4 & $\mathrm{c}$ & $\mathrm{c}$ & $\mathrm{c}$ \\
\hline 39 & BQ106504 & Disulfide isomerase & 46.3 & 3.7 & 55.6 & 5.0 & $\mathrm{c}$ & $\mathrm{c}$ & $\mathrm{c}$ \\
\hline 141 & BQ105675 & Dihydroflavonol reductase & 42.1 & 5.5 & 43.8 & 5.6 & $\mathrm{c}$ & $\mathrm{c}$ & $\mathrm{c}$ \\
\hline 21 & BQ105334 & Hydroxymethyltransferase & 56.6 & 6.8 & 51.7 & 6.8 & $\mathrm{c}$ & $\mathrm{c}$ & $\mathrm{c}$ \\
\hline 60 & BQ104381 & Nucleoside-diphosphate kinase & 17.5 & 6.5 & 16.3 & 7.9 & $\mathrm{~d}$ & $\mathrm{c}$ & $\mathrm{d}$ \\
\hline 34 & BQ104506 & UDP-glucose dehydrogenase & 55.3 & 5.6 & 53.2 & 5.7 & $\mathrm{c}$ & $\mathrm{c}$ & $\mathrm{c}$ \\
\hline
\end{tabular}


Table 4 (Contd.)

\begin{tabular}{|c|c|c|c|c|c|c|c|}
\hline \multirow[t]{2}{*}{$\begin{array}{l}\text { Spot } \\
\text { no. }\end{array}$} & \multirow[t]{2}{*}{$\begin{array}{l}\text { Accession } \\
\text { no. }\end{array}$} & \multirow[t]{2}{*}{$\begin{array}{l}\text { Putative } \\
\text { function/description }\end{array}$} & \multirow[t]{2}{*}{$\begin{array}{l}\text { Exp. } \\
\text { MW (kDa) }\end{array}$} & \multirow[t]{2}{*}{$\begin{array}{l}\text { Exp. } \\
\text { pI }\end{array}$} & \multirow[t]{2}{*}{$\begin{array}{l}\text { Theo. } \\
\text { MW (kDa) }\end{array}$} & \multirow[t]{2}{*}{$\begin{array}{l}\text { Theo. } \\
\text { pI }\end{array}$} & $\begin{array}{l}\text { Expression protein } \\
\text { RNA }\end{array}$ \\
\hline & & & & & & & $1-4$ \\
\hline
\end{tabular}

Protein destination

$\begin{array}{lll}41 & \text { BQ105563 } & \text { Chaperonin } 60 \beta \text { subunit } \\ 83 & \text { BQ105563 } & \text { Chaperonin } 60 \beta \text { subunit } \\ 123 & \text { BQ104538 } & \text { 26S protease regulatory subunit } 7 \\ 47 & \text { CF349909 } & \text { 20S proteasome } \alpha 4 \text { subunit } \\ 71 & \text { CF349832 } & \text { ATP-dependent Clp protease } \\ 72 & \text { CAA05023 } & \text { Succinyl-CoA-ligase } \alpha \text { subunit } \\ 99 & \text { CF349560 } & \text { Leucyl aminopeptidase }\end{array}$

Cell growth, cell division and DNA synthesis

11 BQ104538 CDC48

Intracellular transport

$52 \quad$ AAF01284

NSF attachment

Ionic homeostasis

43 BQ104264

V-ATPase catalytic subunit A

63.8
65.3
55.3
29.1
91.1
36.0
55.3

$\begin{array}{ll}4.1 & 62.0 \\ 4.9 & 64.1 \\ 6.1 & 47.7 \\ 7.3 & 27.1 \\ 5.2 & 99.5 \\ 6.6 & 36.2 \\ 5.3 & 53.1\end{array}$

62.0

64.1

47.7

99.5

36.2

106.4

$4.7-90.3$

106.4

$4.7 \quad 90.3$

32.0

$\begin{array}{ll}4.5 & 32.8\end{array}$

74.0

$5.2 \quad 68.6$

Unknown function

$1 \quad$ BQ105069

$56 \quad$ BQ105069

$136 \quad$ BQ105069

$26 \quad$ AAC00619

$63 \quad$ CAB52464

73 AAC24091

92 CAB 88540

97 BQ104783

113 AAF99784

138 BQ105155

40 BQ105025

$95 \quad$ CF349367

49 BQ105680

109 BQ105117

Unknown

Unknown

Unknown

Unknown

Unknown

Unknown

Unknown

Unknown

Unknown

Unknown

Unknown

Unknown

Unknown

Unknown

Unknown

18.1

18.1

18.8

36.3

74.6

27.7

29.5

28.4

47.6

18.7

32.5

14.4

20.0

46.3

36.3

No hits found

$\begin{array}{ll}102 & \text { BQ104241 } \\ 78 & \text { BQ104638 } \\ 106 & \text { CF349612 } \\ 84 & \text { BQ104395 } \\ 132 & \text { BQ105170 } \\ 37 & \text { BQ104971 } \\ 80 & \text { BQ106227 }\end{array}$

No hits found

No hits found

No hits found

No hits found

No hits found

No hits found

No hits found

32.0
73.3
59.3
62.0
27.7
30.2
42.7

$\begin{array}{ll}5.2 & 68.6 \\ & \\ 4.9 & 17.1 \\ 4.6 & 17.1 \\ 4.3 & 17.1 \\ 4.6 & 39.9 \\ 4.9 & 78.8 \\ 3.9 & 18.9 \\ 4.7 & 18.6 \\ 4.9 & 27.1 \\ 5.1 & 46.1 \\ 5.6 & 22.7 \\ 4.4 & 32.6 \\ 4.6 & 16.6 \\ 3.7 & 19.0 \\ 4.6 & 41.2 \\ 5.5 & 41.6\end{array}$

5.2
5.6
6.0
6.9
8.8
8.6
5.4

$\begin{array}{lll}\mathrm{u} & \mathrm{c} & \mathrm{c} \\ \mathrm{d} & \mathrm{u} & \mathrm{c} \\ \mathrm{d} & \mathrm{d} & \mathrm{c} \\ \mathrm{d} & \mathrm{d} & \mathrm{c} \\ \mathrm{u} & \mathrm{c} & \mathrm{c} \\ \mathrm{c} & \mathrm{c} & \\ \mathrm{u} & \mathrm{c} & \mathrm{c}\end{array}$

Proteins were classified into functional groups according to the Munich Information Center for Protein Sequences (MIPS). Expression pattern of proteins during flower development from stage 1 to 4 and from stage 4 to 6 , determined as in Table 3, is presented. Expression pattern of corresponding RNA during

emitted by the flowers (Dudareva et al. 2000). Hence, during flower development from stages 1 to 6 , we expected to see mainly increases/decreases in protein levels, and not the drastic changes in protein composition found here, i.e. $30 \%$ of the proteins being stage-specific.

During the transition from stage 1 to 4 , the levels of ca. $55 \%$ of the proteins decreased. A more balanced number of up- and downregulated proteins characterized further development of the petals from stage 4 to 6 . The initial massive downregulation of proteins may be indicative of the transition from one developmental program to another, i.e. from cell division to cell expansion. Indeed, protein \#11, whose level was downregulated during the flower development from stage 1 to 4 was determined by microarray (Guterman et al. 2002; Izhaki 2004). Protein spots corresponding to the same gene are clusteredExpression pattern: $c$ constitutive, $u$ upregulated, $d$ downregulated. Exp experimental, Theo theoretical

petal transition from stage 1 to 4 , was identified as a homologue of cell-division-cycle protein cdc 48 (Thoms 2002), lending support to this notion.

The transition from stage 1 to 4 is also accompanied by the accumulation of anthocyanin (Table 1; Ben-Meir et al. 2002) and the disintegration of chloroplast components (Vainstein and Sharon 1993). Indeed, the level of chloroplast Clp protease (protein \#71) increases in petals during the transition from stage 1 to 4 . On the other hand, the level of dihydroflavonol reductase (protein \#141), the only representative of the anthocyanin biosynthetic pathway identified in this study, remains constant during pigment accumulation (stages 1 to 4 ). 


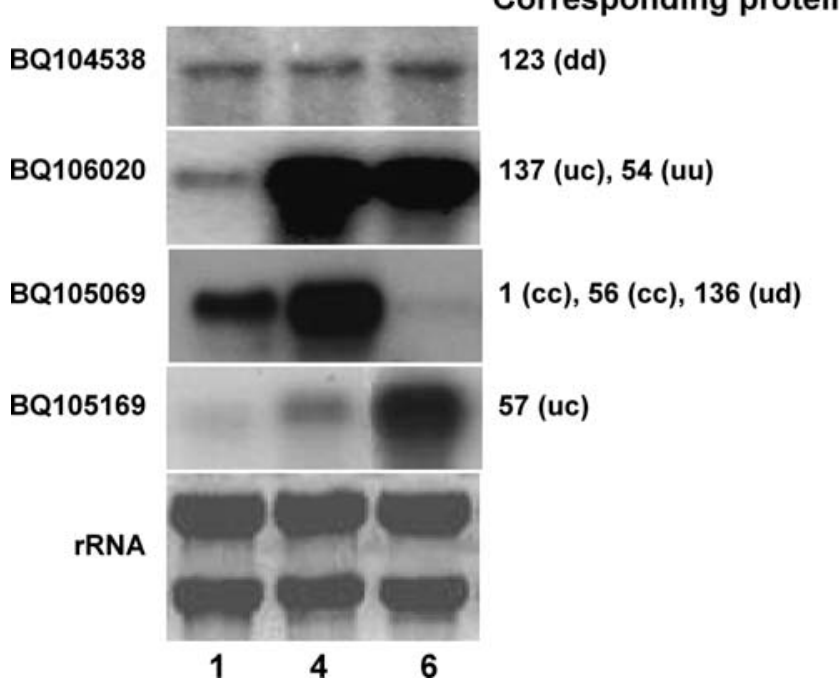

Fig. 4 Comparison of RNA expression pattern with that of its corresponding protein during rose flower development. Total RNA was extracted from petals at three developmental stages and northern blot analysis was performed with four different genes. rRNA is presented for comparison. Corresponding proteins (spot numbers) and their pattern of expression ( $c$, constitutive, $u$ upregulated, $d$ downregulated) during petal development from stage 1 to 4 and from stage 4 to 6 are presented. First letter in parentheses indicates expression pattern from stage 1 to 4 , and the second letter from stage 4 to 6

Classification of the annotated proteins into functional groups revealed energy, cell rescue, unknown function (including novel sequences) and metabolism to be the largest classes, together comprising ca. $90 \%$ of all identified proteins. Interestingly, a large number of stress-related proteins were identified in the developing petals, including low- and high-molecular-weight HSPs, peroxidase, superoxide dismutase, and catalase. This is not surprising as many stress-related genes are active in developing rose petals (Channeliere et al. 2002; Guterman et al. 2002). Another representative of this group was the homologue of a chromoplast carotenoid-associated protein (spot \#32). It should be noted that Fragrant Cloud petals do not accumulate chromoplasts or carotenoids. However, these proteins have been shown to be involved not only in chromoplastogenesis during flower development, but also in protection against biotic and abiotic stresses (Langenkamper et al. 2001). The large proportion of stress-related proteins in developing petals is not unique to rose. In both Arabidopsis and Antirrhinum, stress-related genes represent a large proportion of the petal ESTs and are regulated by a class B floral homeotic gene (Zik and Irish 2003; Bey et al. 2004). The stress-related hormone jasmonic acid has also been shown to accumulate to high levels in developing flowers (Meyer et al. 1984). The accumulation of stress-related proteins in petals may be indicative of the requirement for protection of the cell during flower development against either intracellular stress (e.g. an oxidative environment) or external stresses. The flower in general, petals in particular, are extremely sensitive tissues and even mild biotic or abiotic stress conditions can lead to organ death.

Despite the fact that secondary metabolism-related pathways are highly active in advanced stages of petal development (Francis and Allcock 1969; Suzuki et al. 2000), only one identified protein, namely dihydroflavonol reductase, could be directly related to secondary metabolism. This can be explained by the low level of relevant enzymes, membrane association, etc. It should also be noted that only a limited number of proteins were annotated: ca. $10 \%$ of the total identified by us and only ca. $1 \%$ of the putative total number of petal proteins.

We analyzed the expression pattern during flower development of four gene products at the RNA level. To a large extent, the pattern of expression of the corresponding proteins did not correlate with the respective transcript levels. Similar discrepancies were also revealed when the expression patterns of 65 proteins were evaluated on the basis of microarray analyses. This is not unexpected since in several cases (e.g. BQ105069) we show that the same gene corresponds to several different protein spots, which differ in their expression patterns. It is likely that at least some of these protein isoforms result from post-translational modifications. Furthermore, the generation of isoforms due to alternative splicing cannot be excluded (Jordan et al. 2002). We also cannot dismiss the idea that such groups of proteins result from recent gene duplication and/or allelic variation, especially since cv. Fragrant Cloud is tetraploid. In this case, the differences in expression at the transcript level between such closely related genes cannot be revealed by either RNA blot or cDNA array. To overcome this limitation, gene-specific probes must be used; however in our case, this was not an option since full-length sequences of the transcript/proteins are still unavailable.

In this work, the rose petal proteome was analyzed during flower development. The stage-specific protein maps generated here should be highly instrumental in producing detailed analyses of the late processes of flower development. In-depth characterization of gene expression at the protein level, and not only at the RNA level, is essential for understanding such complex biological processes.

Acknowledgements This work was supported by The University Intramural Research Fund Basic Project Awards, by Research Grant Number US-3437-03 from BARD and by the Israel Science Foundation. EP was the recipient of a Forchheimer Visiting Professor Fellowship from the Hebrew University of Jerusalem. We thank Drs. Arie Admon and Tamar Ziv of the Protein Center, Technion, Haifa, Israel for assisting us with the MS analyses, and Gil Shalev for plant culture.

\section{References}

Aubert D, Chen L, Moon Y-H, Martin D, Castle LA, Yang C-H, Sung ZR (2001) EMF1, a novel protein involved in the control of shoot architecture and flowering in Arabidopsis. Plant Cell 13:1865-1875 
Bae MS, Cho EJ, Choi EY, Park OK (2003) Analysis of the Arabidopsis nuclear proteome and its response to cold stress. Plant J 36:652-663

Bardel J, Louwagie M, Jaquinod M, Jourdain A, Luche S, Rabilloud T, Macherel D, Garin J, Bourguignon J (2002) A survey of the plant mitochondrial proteome in relation to development. Proteomics 2:880-898

Ben-Meir H, Zuker A, Weiss D, Vainstein A (2002) Molecular control of floral pigmentation: anthocyanins. In: Vainstein A (ed) Breeding for ornamentals: classical and molecular approaches. Kluwer, Dordrecht, pp 253-272

Bey M, Stüber K, Fellenberg K, Schwarz-Sommer Z, Sommer H, Saedler H, Zachgo S (2004) Characterization of Antirrhinum petal development and identification of target genes of the class B MADS box gene DEFICIENS. Plant Cell 16:3197-3215

Channeliere S, Riviere S, Scalliet G, Jullien F, Szecsi J, Dolle C, Vergne P, Dumas C, Bendahmane M, Hugueney P, Cock JM (2002) Analysis of gene expression in rose petals using expressed sequence tags. FEBS Lett 515:35-38

Chmelnitsky I, Azizbekova N, Khayat E, Zieslin N (2002) Morphological development of normal and phyllody-expressing Rosa hybrida cv. Motrea flowers. Plant Growth Regul 37:215-221

Dudareva N, Murfitt LM, Mann CJ, Gorenstein N, Kolosova N, Kish CM, Bonham C, Wood K (2000) Developmental regulation of methyl benzoate biosynthesis and emission in snapdragon flowers. Plant Cell 12:949-961

Dudareva N, Pichersky E, Gershenzon J (2004) Biochemistry of plant volatiles. Plant Physiol 135:1893-1902

Francis MJO, Allcock C (1969) Geraniol beta-D-glucoside; occurrence and synthesis in rose flowers. Phytochemistry 8:1339-1347

Gallardo K, Job C, Groot SP, Puype M, Demol H, Vandekerckhove J, Job D (2001) Proteomic analysis of arabidopsis seed germination and priming. Plant Physiol 126:835-848

Gallardo K, Job C, Groot SP, Puype M, Demol H, Vandekerckhove J, Job D (2002) Proteomics of Arabidopsis seed germination. A comparative study of wild-type and gibberellindeficient seeds. Plant Physiol 129:823-837

Gallardo K, Le Signor C, Vandekerckhove J, Thompson RD, Burstin J (2003) Proteomics of Medicago truncatula seed development establishes the time frame to reserve accumulation. Plant Physiol 133:1-19

Gorg A, Boguth G, Obermaier C, Weiss W (1998) Two-dimensional electrophoresis of proteins in an immobilized $\mathrm{pH} 4-12$ gradient. Electrophoresis 19:1516-1519

Guterman I, Shalit M, Menda N, Piestun D, Dafny-Yelin M, Shalev G, Davydov O, Ovadis M, Emanuel M, Wang J, Adam Z, Pichersky E, Lewinsohn E, Zamir D, Vainstein A, Weiss D (2002) Rose scent: genomic approach to discover novel floral fragrance-related genes. Plant Cell 14:2325-2338

Gygi SP, Rochon Y, Franza BR, Aebersold R (1999) Correlation between protein and mRNA abundance in yeast. Mol Cell Biol 19:1720-1730

Izhaki E (2004) Genomic approach to studying rose floral scent. Thesis, The Hebrew University of Jerusalem

Johnson MD, Yu LR, Conrads TP, Kinoshita Y, Uo T, Matthews JD, Lee SW, Smith RD, Veenstra TD, Morrison RS (2004) Proteome analysis of DNA damage-induced neuronal death using high throughput mass spectrometry. J Biol Chem 279:26685-26697

Jordan T, Schornack S, Lahaye T (2002) Alternative splicing of transcripts encoding toll-like plant resistance proteins-what's the functional relevance to innate immunity? Trends Plant Sci 7:392-398

Kotilainen M, Helariutta Y, Mehto M, Pollanen E, Albert VA, Elomaa P, Teeri TH (1999) GEG participates in the regulation of cell and organ shape during corolla and carpel development in Gerbera hybrida. Plant Cell 11:1093-1104

Kruft V, Eubel H, Jansch L, Werhahn W, Braun HP (2001) Proteomic approach to identify novel mitochondrial proteins in Arabidopsis. Plant Physiol 127:1694-1710

Krussmann G (1981) The complete book of rose. Timber Press, Portland
Langenkamper G, Manach N, Broin M, Cuine S, Becuwe N, Kuntz M, Rey P (2001) Accumulation of plastid lipid associated proteins (fibrillin/CDSP34) upon oxidative stress, ageing and biotic stress in Solanacea and in response to drought in other species. J Exp Bot 52:1545-1554

Lavid N, Wang J, Shalit M, Guterman I, Bar E, Beuerle T, Menda N, Shafir S, Zamir D, Adam Z, Vainstein A, Weiss D, Pichersky E, Lewinsohn E (2002) $O$-Methyltransferases involved in the biosynthesis of volatile phenolic derivatives in rose petals. Plant Physiol 129: 1899-1907

Martin C, Gerats T (1993) Control of pigment biosynthesis genes during petal development. Plant Cell 5:1253-1264

Meyer A, Miersch O, Buttner C, Dathe W, Sembdner G (1984) Occurrence of the plant growth regulator jasmonic acid in plants. J Plant Growth Regul 3:1-8

Peck SC, Nuhse TS, Hess D, Iglesias A, Meins F, Boller T (2001) Directed proteomics identifies a plant-specific protein rapidly phosphorylated in response to bacterial and fungal elicitors. Plant Cell 13:1467-1475

Peltier JB, Friso G, Kalume DE, Roepstorff P, Nilsson F, Adamska I, van Wijk KJ (2000) Proteomics of the chloroplast: systematic identification and targeting analysis of lumenal and peripheral thylakoid proteins. Plant Cell 12:319-341

Raguso RA, Pichersky E (1995) Floral volatiles from Clarkia breweri and Clarkia concinna (Onagraceae): recent evolution of floral scent and moth pollination. Plant Syst Evol 194:55-67

Roberts JKM (2002) Proteomics and a future generation of plant molecular biologists. Plant Mol Biol 48:143-154

Rolland-Lagan A-G, Bangham JA, Coen E (2003) Growth dynamics underlying petal shape and asymmetry. Nature 422:161-163

Sablowski WM, Meyerowitz EM (1998) A homolog of NO API$C A L M E R I S T E M$ is an immediate target of the floral homeotic genes APETALA3/PISTILLAT. Cell 92:93-103

Shalit M, Guterman I, Volpin H, Bar E, Tamari T, Menda N, Adam Z, Zamir D, Vainstein A, Weiss D, Pichersky E, Lewinsohn E (2003) Volatile ester formation in roses: identification of an Acetyl-CoA: geraniol/citronellol acetyltransferase in developing rose petals. Plant Physiol 131:1868-1876

Suzuki K, Tsuda S, Fukui Y, Fukuchi-Mizutani M, YonekuraSakakibara K, Tanaka Y, Kusumi T (2000) Molecular characterization of rose flavonoid biosynthesis genes and their application in petunia. Biotechnol Biotechnol Equip 14:56-62

Taylor NL, Heazlewood JL, Day DA, Millar AH (2004) Lipoic acid-dependent oxidative catabolism of alpha-keto acids in mitochondria provides evidence for branched-chain amino acid catabolism in Arabidopsis. Plant Physiol 134:838-848

Thoms S (2002) Cdc48 can distinguish between native and non-native proteins in the absence of cofactors. FEBS Lett 520:107-110

Vainstein A, Sharon R (1993) Biogenesis of petunia and carnation corolla chloroplasts: changes in the abundance of nuclear and plastid-encoded photosynthesis-specific gene products during flower development. Physiol Plant 89:192-198

Vainstein A, Lewinsohn E, Pichersky E, Weiss D (2001) Floral fragrance-new inroads into an old commodity. Plant Physiol 127:1383-1389

VBN (1995) Vereniging van Bloemenveilingen in Nederland, Statistiek Boeck

Watson BS, Asirvatham VS, Wang L, Sumner LW (2003) Mapping the proteome of barrel medic (Medicago truncatula). Plant Physiol 131:1104-1123

Weiss D (2000) Regulation of flower pigmentation and growth: multiple signaling pathways control anthocyanin synthesis in expanding petals. Physiol Plant 110:152-157

Yu H, Ito T, Zhao YX, Peng JR, Kumar P, Meyerowitz EM (2004) Floral homeotic genes are targets of gibberellin signaling in flower development. Proc Natl Acad Sci USA 101:7827-7832

Zik M, Irish VF (2003) Global identification of target genes regulated by APETALA3 and PISTILLATA floral homeotic gene action. Plant Cell 15:207-222

Zuker A, Tzfira T, Vainstein A (1998) Cut-flower improvement using genetic engineering. Biotech Adv 16:33-79 